\section{Analisis Suasana Toko, Potongan Harga Dan Penataan Produk Terhadap Pembelian Impulsif}

Store Atmosphere and Impulse Buying

\author{
Nadia Safitri ${ }^{1)}$, Prasetyo Hadi'2), Bernadin Dwi M ${ }^{3)}$ \\ Universitas Pembangunan Nasional Veteran Jakarta \\ E-mail: nsnadia72@gmail.com, prasetyohadi1960@gmail.com²), \\ bernadindwim@yahoo.com ${ }^{3)}$
}

Submitted: SEPTEMBER 2020

\begin{abstract}
This research is a quantitative study that aims to determine the effect of the atmosphere of the store, price discounts and product arrangement on impulsive purchases. The population in this study are consumers who have shopped at the Ramayana Department Store in the Jakarta area. Sample size was taken as many as 75 respondents, with non-probability sampling methods especially purposive sampling. Data collection in this study was carried out through questionnaires. The analysis technique used is the PLS (Partial Least Square) analysis method with SmartPLS software version 3.0. The results of this study indicate that (1) store atmosphere does not affect impulsive purchases with a path coefficient of 0.067. (2) the price discount significantly influences impulsive purchases with a path coefficient of 0.417. (3) product structuring significantly influences impulsive purchases with a path coefficient of 0.482 .
\end{abstract}

Keywords: Store Atmosphere, Price Discount, Display Product, Impulse Buying

\begin{abstract}
ABSTRAK
Penelitian ini merupakan penelitian kuantitatif yang bertujuan untuk mengetahui pengaruh dari suasana toko, potongan harga dan penataan produk terhadap pembelian impulsif. Populasi dalam penelitian ini adalah konsumen yang pernah berbelanja di Ramayana Department Store di wilayah Jakarta. Ukuran Sampel diambil sebanyak 75 orang responden, dengan metode non probability sampling khususnya purposive sampling. Pengumpulan data dalam penelitian ini dilakukan melalui penyebaran kuesioner. Teknik analisis yang dipakai adalah metode analisis PLS (Partial Least Square) dengan software $S m a r t P L S$ versi 3.0. Hasil dari penelitian ini menunjukkan bahwa (1) suasana toko tidak berpengaruh terhadap pembelian impulsif dengan nilai koefisien jalur sebesar 0,067. (2) potongan harga berpengaruh secara signifikan terhadap pembelian impulsif dengan nilai koefisien jalur sebesar 0,417 . (3) penataan produk berpengaruh secara signifikan terhadap pembelian impulsif dengan nilai koefisien jalur sebesar 0,482.
\end{abstract}

Kata kunci: Suasana Toko, Potongan Harga, Penataan Produk, Pembelian Impulsif

\section{PENDAHULUAN}

Usaha bisnis ritel di Indonesia seiring berjalannya waktu mengalami pertumbuhan yang sangat pesat dari tahun ke tahun. Dengan adanya hal tersebut, para pelaku usaha pun terdorong untuk lebih berinovasi dan proaktif dalam memberikan dan menciptakan produk maupun pelayanan yang baik agar dapat unggul dari para pesaing untuk memenangkan pangsa pasar. Gaya hidup masyarakat yang semakin hari semakin berkembang maju mengikuti perubahan zaman ini secara langsung mengubah pola pikir dan tingkah laku manusia dengan menginginkan sesuatu hal yang serba praktis dan ringkas. Perkembangan zaman yang semakin modern dapat dijadikan acuan untuk

\section{JIMKES}

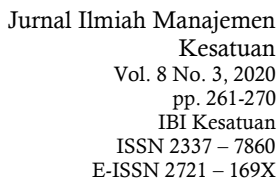


Store Atmosphere and Impulse Buying

\section{2}

mengembangkan setiap kegiatan dan usaha disetiap sektor seperti teknologi, perindustrian dan juga infrastruktur. Maka dari itu para peritel juga harus mampu menciptakan sesuatu yang lebih untuk menyesuaikan pola pikir dan juga gaya hidup para masyarakat yang semakin modern. Dengan demikian, secara langsung akan mengakibatkan meningkatnya daya beli masyarakat dan terdorong untuk berbelanja berbagai macam produk yang diinginkan atau hanya sebagai kebutuhan sehari-hari.

Pada tahun 2019 bisnis ritel ditaksir mencapai pertumbuhan sebesar 10\% atau senilai Rp256 triliiun. Hal ini diungkapkan oleh Tutum Rahanta selaku Wakil Ketua Asosiasi Pengusaha Ritel di Indonesia (APRINDO). Tatum Rahanta mengatakan bahwa ia optimis bisnis ritel dapat mencapai pertumbuhan lebih dari $10 \%$ meskipun pada tahun 2017 bisnis ritel hanya mampu mencapai pertumbuhan 3,7\%. Pada tahun 2016 bisnis ritel mencapai angka Rp205 triliun. Kemudian tahun 2017 bisnis ritel tumbuh mencapai nilai Rp212 triliun dan terakhir pada tahun 2018 pertumbuhan bisnis ritel mencapai angka Rp233 triliun. Bahkan pertumbuhan 2017 ke 2018 jauh lebih tinggi dibandingkan tahun 2016 ke tahun 2017. Ini bisa menjadi sinyal positif untuk pertumbuhan bisnis ritel pada tahun 2019. (Richard, 2019)

Pada data Top Brand Award, Ramayana mengalami peningkatan ditahun 2016 sebesar 5.9\% dan ditahun 2017 sebesar 3.7\%. Namun pada tahun 2018 Ramayana mengalami penurunan persentase sebesar 3.3\%, dan di tahun 2019 terlihat bahwa terjadinya penurunan secara drastis sebesar 9.1\%. Hal ini bisa dipengaruhi dari banyaknya para kompetitor baru yang datang ke Indonesia dan semakin meningkatnya tingkat belanja online di Indonesia dan didukung dengan semakin banyaknya perusahaan teknologi e-commerce yang bermunculan.

Dari tiap-tiap individu mempunyai perilaku yang berbeda untuk melakukan suatu pembelian produk, maka dari itu para individu juga memiliki cara bagaimana mereka memilih suatu produk dan memutuskan untuk membelinya. Sebelum dilakukan pembelian biasanya para konsumen akan merencanakan produk apa saja yang akan dibeli, harganya, jumlah barangnya, ukuran, dan dimana konsumen akan membeli produk. Melihat adanya perilaku yang berbada dari tiap konsumen dalam kegiatan melakukan pembelian suatu produk, maka penelitian terhadap pembelian impulsif konsumen Ramayana ini menjadi hal yang sifatnya penting. Penelitian ini bertujuan untuk mengetahui apa saja hal-hal yang dapat mempengaruhi konsumen untuk melakukan kegiatan pembelian suatu produk.

Mengacu pada latar belakang yang telah disampaikan, maka perumusan masalah dalam penelitian ini yakni sebagai berikut:

a. Apakah Suasana Toko berpengaruh terhadap pembelian impulsif pada konsumen Ramayana Cabang Semper?

b. Apakah Potongan Harga berpengaruh terhadap pembelian impulsif pada konsumen Ramayana Cabang Semper?

c. Apakah Penataan Produk berpengaruh terhadap pembelian impulsif pada konsumen Ramayana Cabang Semper?

\section{Model Penelitian Empirik}

\section{Suasana Toko terhadap Pembelian Impulsif}

Menurut Kotler dan Armstrong (2012) dalam Sunawarman ((2018) menerangkan bahwa store atmosphere adalah suasana terencana yang sesuai dengan pasar sasarannya dan yang dapat menarik konsumen untuk membeli . Hal ini didukung hasil penelitian Pontoh, dkk (2017) dan Sunawarman (2018) yang membuktikan bahwa suasana toko berpengaruh terhadap pembelian impulsif.

\section{Potongan Harga terhadap Pembelian Impulsif}

Menurut Artana dkk (2019) Price Discount atau potongan harga yaitu salah satu strategi dalam pemasaran yang sering digunakan yang mana dalam hal ini pemasar mencoba menawarkan produk dengan harga lebih rendah daripada harga seharusnya dengan harapan konsumen akan merasa tertarik sebuah produk. Hal ini didukung hasil penelitian 
Maharani dan Darma (2018) dan Artana dkk (2019) yang membuktikan bahwa potongan harga berpengaruh terhadap pembelian impulsif.

Penataan Produk terhadap Pembelian Impulsif

Menurut Utami (2017) Display produk dapat ditata sedemikian rupa, misalnya dipajang dengan cara digantung dan disusun berdasarkan urutan warna, sehingga konsumen yang berada di dalam toko tertarik untuk melihat-lihat produk yang ditawarkan. Muthiah dkk (2018), Artana dkk (2019), Pontoh dkk (2017) yang membuktikan bahwa penataan produk berpengaruh terhadap pembelian impulsif.

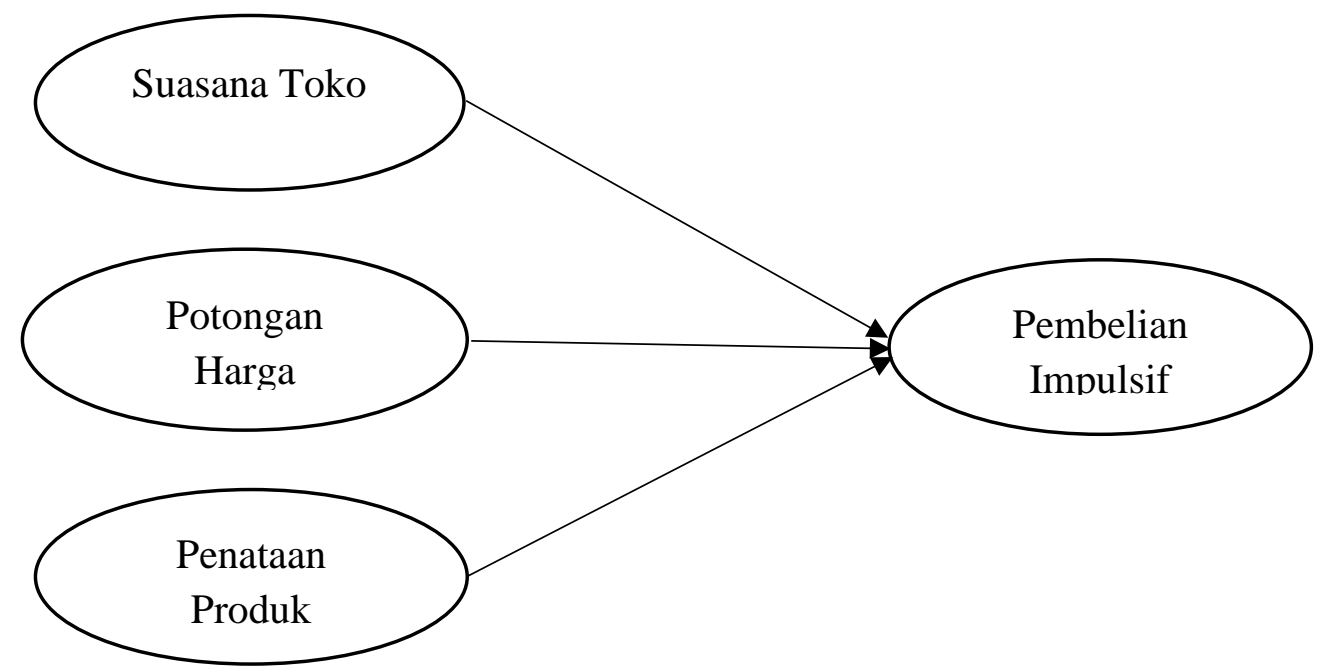

Sumber: data diolah

\section{Hipotesis}

Gambar 1. Model Penelitian Empirik

Hipotesis adalah suatu dugaan sementara mengenai hubungan antara dua variabel atau lebih untuk diuji kebenarannya. Variabel yang diteliti dalam penelitian ini adalah pembelian impulsif yang dipengaruhi oleh suasana toko, potongan harga, dan penataan produk adalah sebagai berikut:

$\mathrm{H} 1$ : diduga suasana toko berpengaruh terhadap pembelian impulsif.

$\mathrm{H} 2$ : diduga potongan harga berpengaruh terhadap pembelian impulsif.

$\mathrm{H} 3$ : diduga penataan produk berpengaruh terhadap pembelian impulsif.

\section{METODOLOGI PENELITIAN}

Definisi Operasional dan Pengukuran Variabel

Tabel 1. Pengukuran Variabel

\begin{tabular}{llll}
\hline Variabel & Dimensi & Indikator & Jenis Data \\
\hline Pembelian & Penawaran menarik & Pure impulse & Likert \\
Impulsif (Y) & Keinginan mencoba & Suggestion impulse & \\
& Mengingat Produk & Reminder impulse & \\
& Harga spesial & Planned impulse & Likert \\
\hline Suasana Toko & & Komunikasi visual & \\
$(\mathrm{X} 1)$ & Cahaya & \\
& & Warna & Likert \\
& Aroma & \\
\hline Potongan Harga & Musik & Likert \\
(X2) & Frekuensi diskon, & \\
\hline Penataan Produk (X3) & Besaran diskon & \\
& & Waktu pemberian diskon & \\
\end{tabular}

Sumber : data diolah
Store Atmosphere and Impulse Buying 
Store Atmosphere

and Impulse

Buying

264

\section{Populasi dan Sampel}

Populasi atau objek dalam penelitian ini adalah konsumen yang pernah berbelanja di Ramayana Department Store di wilayah Jakarta. Dalam penelitian ini teknik pengambilan sampel yang digunakan adalah Non-probability Sampling dengan jenis Purposive Sampling. Yang dimaksud Non-probability Sampling adalah teknik pengambilan sampel yang tidak memberikan peluang atau kesempatan yang sama bagi setiap unsur atau anggota populasi untuk dipilih menjadi sampel (Sugiyono 2014, hlm. 154). Menurut Sugiyono (2014, hlm.156) Purposive Sampling adalah teknik penentuan sampel dengan pertimbangan tertentu.

Adapun kriteria yang ditentukan oleh peneliti sebagai berikut:

a. Laki-laki dan perempuan berusia lebih besar dari 18 tahun.

b. Konsumen yang pernah berbelanja di Ramayana Department Store.

\section{Teknik Pengumpulan Data}

Jenis data yang digunakan dalam penelitian ini adalah data primer. Sumber data yang diperoleh dalam penelitian ini berasal dari data primer yang bersumber langsung dari responden (konsumen yang pernah berbelanja di Ramayana Department Store). Pengumpulan data yang dilakukan oleh peneliti adalah dengan melakukan penyebaran atau membagikan kuesioner kepada responden yang merupakan konsumen yang pernah berbelanja di Ramayana Department Store cabang Semper. Kuesioner yang diberikan kepada reponden bertujuan untuk dapat mengukur variabel-variabel yang diteliti, yaitu variabel Suasana Toko, Potongan Harga, dan Penataan Produk terhadap variabel Pembelian Impulsif yang diukur menggunakan skala likert.

\section{Teknik Analisis Data}

Pada penelitian ini, analisis yang digunakan pada penelitian ini adalah analisis deskriptif dengan bantuan software Partial Least Square(PLS). Uji Kualitas Data dilakukan dengan uji validitas, uji reliabilitas dan uji asumsi klasik.

\section{HASIL DAN PEMBAHASAN Deskripsi Objek Penelitian}

Ramayana Departement Store didirikan oleh Bapak Paulus Tumewu pada tahun 1974, yang berawal dari sebuah toko busana sederhana di jalan.H. Agus salim (Sabang) Jakarta Pusat. Usaha Paulus di bisnis eceran ini memang tak terlepas dari latar belakang keluarganya sendiri yang sebagian besar memang bergelut dalam usaha eceran. Mereka telah membayangkan sebuah Departement Store yang menjual barang-barang berkualitas dengan harga terjangkau untuk segmen berpengasilan menengah ke bawah.

Pada tahun 1989 Ramayana telah menjadi jaringan ritel, yang terdiri dari 13 gerai dan mempekerjakan sebanyak 2.500 pekerja. Mereka menjual berbagai produk dan juga menjadi luas untuk mencakup kebutuhan rumah tangga, mainan dan alat tulis. Tak lama kemudian, pada tahun 1993 pusat perbelanjaan one stop shopping dilaksanakan disetiap toko Ramayana karena jangkauan produk dan harga yang terjangkau.

Ramayana selalu terus tumbuh dan menjadi lebih banyak dan terus membangun sebuah jaringan ritel yang semakin besar. Pada saat ini, Ramayana sudah mengoperasikan sebanyak 105 gerai yang tersebar di 42 kota besar dan mempekerjakan sebanyak 17.867 karyawannya. Dan saat ini perusahaan dari keluarga tradisional ini telah berkembang dan menjadi sebuah bisnis raksasa dalam ritel modern.

Deskripsi Data Responden

Tabel 2. Karakteristik Responden Berdasarkan Jenis Kelamin

\begin{tabular}{ccc}
\hline Jenis Kelamin & Frekuensi & Persentase \\
\hline Laki-laki & 22 & $29 \%$ \\
Perempuan & 53 & $71 \%$ \\
Total & 75 & $100 \%$ \\
\hline
\end{tabular}

Sumber : data diolah 
Tabel 3. Karakteristik Responden Berdasarkan Usia

\begin{tabular}{ccc}
\hline Usia & Frekuensi & Persentase \\
\hline $18-25$ & 62 & $83 \%$ \\
$25-35$ & 8 & $11 \%$ \\
$>35$ & 5 & $6 \%$ \\
Total & 75 & $100 \%$ \\
\hline
\end{tabular}

Sumber : data diolah
Store Atmosphere

and Impulse

Buying

Tabel 4. Karakteristik Responden Berdasarkan Pekerjaan

\begin{tabular}{ccc}
\hline Pekerjaan & Frekuensi & Persentase \\
\hline Mahasiswa & 39 & $52 \%$ \\
Wirausaha & 19 & $25 \%$ \\
Pegawai negeri/ & 5 & $7 \%$ \\
Swasta & & \\
Lain-lain & 12 & $16 \%$ \\
Total & 75 & $100 \%$ \\
\hline
\end{tabular}

Sumber : data diolah

Tabel 5. Karakteristik Responden Berdasarkan Penghasilan

\begin{tabular}{ccc}
\hline Penghasilan & Frekuensi & Persentase \\
\hline Belum ada penghasilan & 27 & $36 \%$ \\
Rp 500.000 - Rp 1.000.000 & 17 & $23 \%$ \\
Rp 1.000.000 - Rp 5.000.000 & 24 & $32 \%$ \\
> Rp 5.000.000 & 7 & $9 \%$ \\
Total & 75 & $100 \%$ \\
\hline
\end{tabular}

\section{Uji Validitas}

Sumber : data diolah

Hasil uji validitas diagram jalur dengan SmartPLS 3.0 menunjukkan model diagram jalur sebagai berikut:

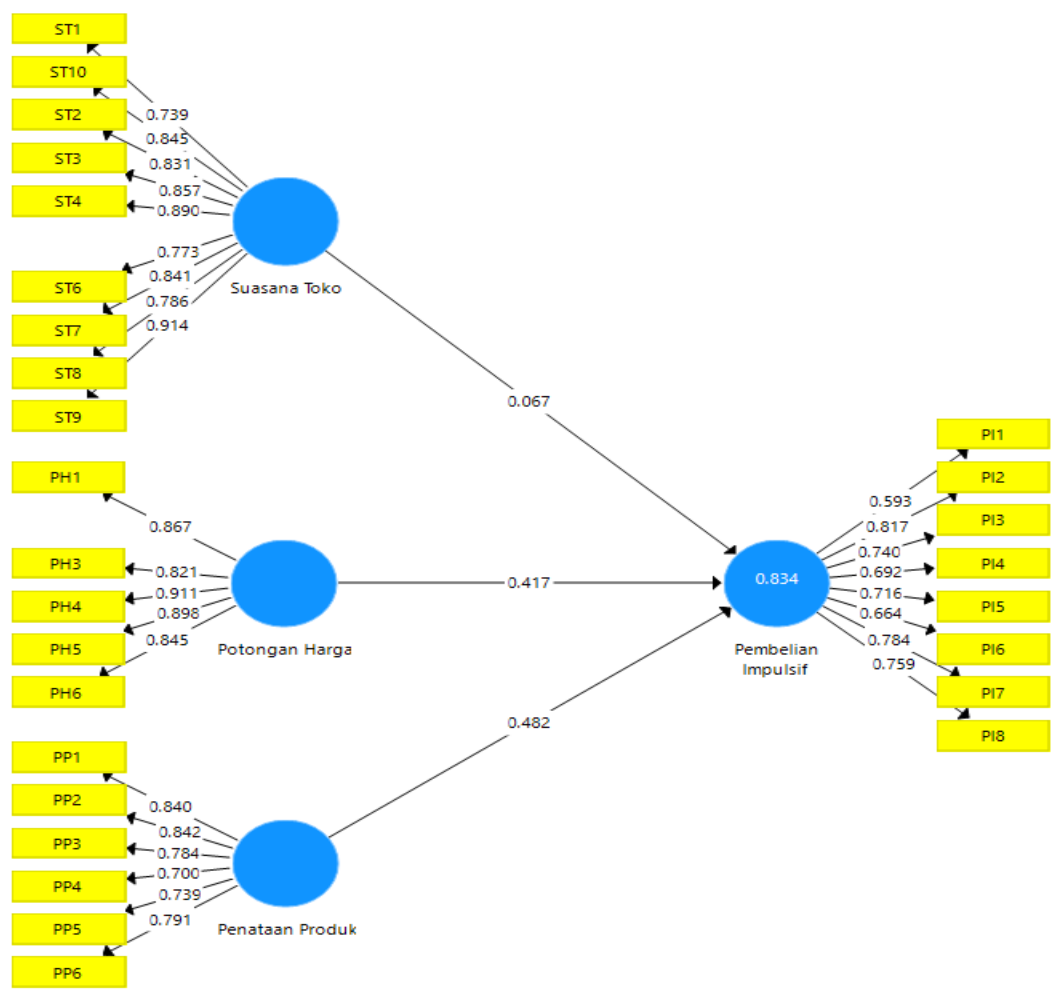

Sumber: Hasil Output PLS

Gambar 2. Outer Model 
Store Atmosphere and Impulse Buying

266
Suatu indikator dikategorikan valid apabila memiliki nilai kolerasi di atas 0,70 . Akan tetapi, pada riset tahap pengembangan, skala loading0,50 sampai 0,60 masih dapat diterima (Ghozali, 2014 hlm. 39)

Uji Validitas Konvergen

Tabel 6. Outer Factor Model

\begin{tabular}{|c|c|c|c|c|}
\hline Indikator & $\begin{array}{c}\text { Pembelian } \\
\text { Impulsif (Y) }\end{array}$ & $\begin{array}{c}\text { Suasana } \\
\text { Toko (X1) }\end{array}$ & $\begin{array}{l}\text { Potongan } \\
\text { Harga (X2) }\end{array}$ & $\begin{array}{c}\text { Penataan } \\
\text { Produk (X3) }\end{array}$ \\
\hline PI1 & 0.593 & & & \\
\hline PI2 & 0.817 & & & \\
\hline PI3 & 0.740 & & & \\
\hline PI4 & 0.692 & & & \\
\hline PI5 & 0.716 & & & \\
\hline PI6 & 0.664 & & & \\
\hline PI7 & 0.784 & & & \\
\hline PI8 & 0.759 & & & \\
\hline ST1 & & 0.739 & & \\
\hline ST10 & & 0.845 & & \\
\hline ST2 & & 0.831 & & \\
\hline ST3 & & 0.857 & & \\
\hline ST4 & & 0.890 & & \\
\hline ST6 & & 0.773 & & \\
\hline ST7 & & 0.841 & & \\
\hline ST8 & & 0.786 & & \\
\hline ST9 & & 0.914 & & \\
\hline PH1 & & & 0.867 & \\
\hline PH3 & & & 0.821 & \\
\hline PH4 & & & 0.911 & \\
\hline PH5 & & & 0.898 & \\
\hline PH6 & & & 0.845 & \\
\hline PP1 & & & & 0.840 \\
\hline PP2 & & & & 0.842 \\
\hline PP3 & & & & 0.784 \\
\hline PP4 & & & & 0.700 \\
\hline PP5 & & & & 0.739 \\
\hline PP6 & & & & 0.791 \\
\hline
\end{tabular}

Sumber: Hasil Output PLS

Tabel 7. Average Variance Extracted (AVE)

\begin{tabular}{lc}
\hline \multicolumn{1}{c}{ Konstruk } & Nilai Average Variance Extracted (AVE) \\
\hline Suasana Toko (X1) & 0.692 \\
Potongan Harga (X2) & 0.756 \\
Penataan Produk (X3) & 0.615 \\
Pembelian Impulsif (Y) & 0.524 \\
\hline
\end{tabular}

Sumber: Hasil Output PLS

Uji Validitas Diskriminan

Tabel 8. Fornell-larcker Criterium

\begin{tabular}{lcccc}
\hline \multicolumn{1}{c}{ Konstruk } & $\begin{array}{c}\text { Pembelian } \\
\text { Impulsif }\end{array}$ & $\begin{array}{c}\text { Penataan } \\
\text { Produk }\end{array}$ & $\begin{array}{c}\text { Potongan } \\
\text { Harga }\end{array}$ & $\begin{array}{c}\text { Suasana } \\
\text { Toko }\end{array}$ \\
\hline Pembelian Impulsif & 0,724 & & & \\
Penataan Produk & 0,874 & 0,784 & & \\
Potongan Harga & 0,862 & 0,811 & 0,869 & \\
Suasana Toko & 0,792 & 0,809 & 0,804 & 0,832 \\
\hline
\end{tabular}

Sumber: Hasil Output PLS 


\begin{tabular}{|c|c|}
\hline Konstruk & Composite Reliability \\
\hline Suasana Toko (X1) & 0,953 \\
\hline Potongan Harga (X2) & 0,939 \\
\hline Penataan Produk (X3) & 0,905 \\
\hline Pembelian Impulsif (Y) & 0,897 \\
\hline
\end{tabular}

Sumber: Hasil Output PLS

Tabel 9. Cronbach's Alpha

\begin{tabular}{lc}
\hline \multicolumn{1}{c}{ Konstruk } & Cronbach's Alpha \\
\hline Suasana Toko (X1) & 0,944 \\
Potongan Harga (X2) & 0,919 \\
Penataan Produk (X3) & 0,874 \\
Pembelian Impulsif (Y) & 0,868 \\
\hline \multicolumn{2}{c}{ Sumber: Hasil Output PLS }
\end{tabular}

\section{Model Struktural (Inner Model)}

Selain model pengukuran (outer model), terdapat pula model struktural (inner model) yang harus diuji dalam penelitian ini. Pengujian ini dilakukan dengan memerhatikan nilai R-Square serta nilai t-statistic hasil output software Smart-PLS. $\mathrm{R}^{2}$ digunakan untuk mengukur seberapa jauh model dalam penelitian mampu menerangkan variasi pada variabel dependen. Hasil output software SmartPLS 3.0 sebagai berikut:

Tabel 10. Nilai $R$ Square dan $R$ Square Adjusted

\begin{tabular}{lcc}
\hline & $R$ Square & $R$ Square Adjusted \\
\hline Pembelian Impulsif & 0,834 & 0,827 \\
\hline
\end{tabular}

Sumber: Hasil Output PLS

Tabel 11. Hasil Uji t-statistic

\begin{tabular}{lccc}
\hline \multicolumn{1}{c}{ Konstruk } & $\begin{array}{c}\text { Original } \\
\text { Sample }(\mathrm{O})\end{array}$ & $\begin{array}{c}\text { T Statistic } \\
(|\mathrm{O} / \mathrm{STDEV}|)\end{array}$ & P Values \\
\hline Suasana Toko - > Pembelian Impulsif & 0,067 & 0,507 & 0,613 \\
Potongan Harga - > Pembelian Impulsif & 0,417 & 3,836 & 0,000 \\
Penataan Produk - > Pembelian Impulsif & 0,482 & 3,446 & 0,001 \\
\hline
\end{tabular}

Sumber: Hasil Output PLS

Berdasarkan hasil uji t-statistic yang dilakukan dalam penelitian ini, berikut adalah gambar inner model yang terbentuk:

Sumber: Hasil Output PLS

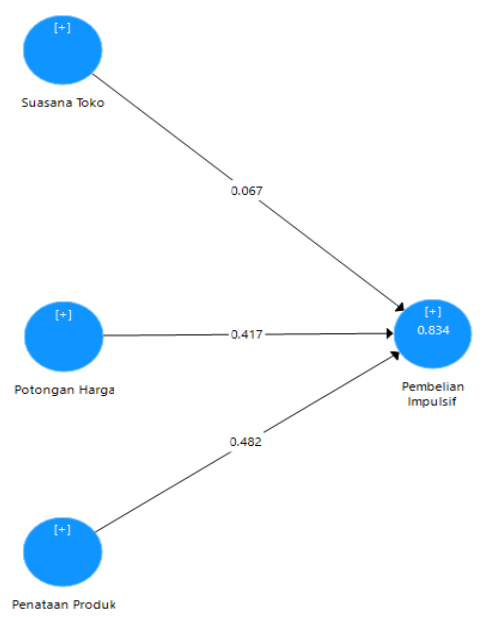

Gambar 3. inner model 
Store Atmosphere

and Impulse

Buying

268

\section{Pembahasan}

Suasana Toko dengan Pembelian Impulsif

Berdasarkan hasil penelitian ini menunjukkan bahwa suasana toko tidak berpengaruh signifikan terhadap pembelian impulsif. Dimana hasil tersebut diperoleh berdasarkan nilai korelasi dari original sample sebesar 0,067 dan hasil uji t statistik menunjukkan nilai $\mathrm{t}_{\text {hitung }} 0,507<\mathrm{t}_{\text {tabel }} 1,994$ dengan nilai signifikan (P Values) sebesar 0,613 $>0,05$. Hal ini menunjukkan bahwa variabel suasana toko tidak berpengaruh dan tidak signifikan terhadap pembelian impulsif konsumen Ramayana Department Store. Artinya, suasana toko Ramayana Department Store memiliki hubungan yang positif dengan pembelian impulsif, tetapi arah hubungan yang positif tersebut tidak mempengaruhi konsumen dalam pembelian impulsif.

Dapat dilihat indikator suasana toko yaitu komunikasi visual, pencahayaan, warna, musik dan aroma yang terdapat di dalam toko Ramayana Department Store sebenarnya sudah baik, namun penerapannya yang kurang dan tidak dapat mempengaruhi konsumen dalam menciptakan pembelian impulsif di Ramayana Department Store. Kemungkinan lain yaitu konsumen tidak begitu tertarik dan tidak terpengaruh dengan suasana yang ada di dalam toko Ramayana Department Store tersebut, karena suasana toko dinilai tidak memberikan manfaat bagi konsumen yang berada di dalam toko Ramayana Department Store yang ingin berbelanja atau sekedar melihat-lihat produk yang ada.

Hasil ini tidak mendukung hipotesis yang diajukan sebelumnya pada penelitian ini, sehingga hipotesis yang telah diajukan sebelumnya ditolak. Hasil ini bertolak belakang dengan penelitian yang dilakukan oleh Darmayasa dan Sukaatmadja (2017) dan Parsad dkk (2019) dalam penelitiannya menunjukkan bahwa suasana toko berpengaruh signifikan terhadap pembelian impulsif. Sejalan dengan penelitian yang dilakukan oleh Artana dkk (2019) yang dalam penelitiannya menunjukkan bahwa store atmosphere atau suasana toko tidak mempunyai pengaruh yang signifikan terhadap pembelian impulsif.

\section{Potongan Harga dengan Pembelian Impulsif}

Berdasarkan hasil penelitian ini menunjukkan bahwa potongan harga berpengaruh signifikan terhadap pembelian impulsif. Dimana hasil tersebut diperoleh berdasarkan nilai korelasi dari original sample sebesar 0,417 dan hasil uji t statistik menunjukkan nilai $\mathrm{t}_{\text {hitung }} 3,836>\mathrm{t}_{\text {tabel }} 1,994$ dengan nilai signifikan ( $\mathrm{P}$ Values) sebesar $0,000<0,05$. Hal ini menunjukkan bahwa variabel potongan harga berpengaruh signifikan terhadap pembelian impulsif konsumen Ramayana Department Store. Artinya, potongan harga yang dilakukan Ramayana memberikan dampak positif bagi para konsumen untuk melakukan pembelian impulsif di Ramayana Department Store.

Dapat dilihat dari indikator potongan harga yaitu frekuensi diskon, besaran diskon dan waktu pemberian diskon memberikan kontribusi pada konsumen yang berkunjung ke Ramayana Department Store untuk melakukan pembelian impulsif. Potongan harga digunakan untuk meningkatkan penjualan secara cepat bagi para ritel dan mendorong langsung para konsumen untuk melakukan pembelian saat itu juga tanpa adanya rencana sebelumnya untuk melakukan pembelian produk tersebut. Kemungkinan lain adalah konsumen merasa tertarik dan terpengaruh dengan adanya potongan harga dari tiap produk yang dijual oleh Ramayana Department Store tersebut. Hasil ini mendukung hipotesis yang diajukan sebelumnya pada penelitian ini, sehingga hipotesis yang telah diajukan sebelumnya diterima. Hasil ini sejalan dengan penelitian yang dilakukan oleh Artana dkk (2019) dan Sari \& Faisal (2018) yang dalam penelitiannya menunjukkan bahwa potongan harga berpengaruh signifikan terhadap pembelian impulsif.

\section{Penataan Produk dengan Pembelian Impulsif}

Berdasarkan hasil penelitian ini menunjukkan bahwa penataan produk berpengaruh signifikan terhadap pembelian impulsif. Dimana hasil tersebut diperoleh berdasarkan nilai korelasi dari original sample sebesar 0,482 dan hasil uji t statistik menunjukkan nilai $t_{\text {hitung }} 3,446>t_{\text {tabel }} 1,994$ dengan nilai signifikan ( $P$ Values) sebesar 0,001 $<0,05$. Hal ini menunjukkan bahwa variabel penataan produk berpengaruh signifikan terhadap 
pembelian impulsif konsumen Ramayana Department Store. Artinya, penataan produk yang dilakukan Ramayana memberikan dampak positif bagi para konsumen untuk melakukan pembelian impulsif di Ramayana Department Store.

Dapat dilihat dari indikator-indikator penataan produk yaitu interior display, eksterior display, dan window display memberikan kontribusi pada konsumen yang berkunjung ke Ramayana Department Store untuk melakukan pembelian impulsif. Penataan produk digunakan untuk menciptakan tampilan yang semenarik mungkin untuk produk-produk yang dipajang dan dijual di dalam toko Ramayana Department Store. Sehingga konsumen akan merasa nyaman dan memudahkan mereka dalam melakukan pencarian dan secara tidak langsung akan timbul pembelian yang tidak direncanakan atau pembelian impulsif.

Hasil ini mendukung hipotesis yang diajukan sebelumnya pada penelitian ini, sehingga hipotesis yang telah diajukan sebelumnya diterima. Hasil ini sejalan dengan penelitian yang dilakukan oleh Artana dkk (2019) dan Muthiah dkk (2018) yang dalam penelitiannya menunjukkan bahwa penataan produk berpengaruh signifikan terhadap pembelian impulsif.

\section{PENUTUP}

Berdasarkan dari hasil analisis dan juga pembahasan yang telah dijelaskan pada bab sebelumnya melalui analisis PLS (Partial Least Square) 3.0 mengenai Pengaruh Suasana Toko, Potongan Harga dan Penataan Produk terhadap Pembelian Impulsif Konsumen Ramayana Department Store serta pengujian yang sudah dilakukan maka dapat disimpulkan sebagai berikut:

a. Suasana Toko tidak berpengaruh terhadap Pembelian Impulsif konsumen Ramayana Department Store. Artinya, Ramayana kurang baik dalam meningkatkan hal-hal yang ada pada suasana toko sehingga tidak mempengaruhi terjadinya pembelian impulsif yang dilakukan konsumen. Hal ini tidak sesuai dengan hipotesis yang sudah dibuat oleh peneliti yaitu suasana toko berpengaruh terhadap pembelian impulsif.

b. Potongan Harga berpengaruh signifikan terhadap Pembelian Impulsif konsumen Ramayana Department Store. Artinya, potongan harga yang dilakukan oleh Ramayana untuk setiap produk yang dijualnya dapat memberikan dampak yang cukup baik, sehingga para konsumen yang datang akan terdorong untuk melakukan pembelian yang tidak direncanakan atau pembelian impulsif. Hal ini sesuai dengan hipotesis yang dibuat oleh peneliti yaitu potongan harga berpengaruh terhadap pembelian impulsif.

c. Penataan Produk berpengaruh signifikan terhadap Pembelian Impulsif pada konsumen Ramayana Department Store. Artinya, semakin baik penataan produk yang dilakukan pada toko Ramayana, maka akan semakin tinggi terjadinya pembelian impulsif. Hal ini sesuai dengan hipotesis yang sudah dibuat oleh peneliti yaitu penataan produk berpengaruh terhadap pembelian impulsif

\section{DAFTAR PUSTAKA}

[1] Artana, I. P., Wisesa, I. G., Setiawan, I. K., Utami, N. L., Yasa, N. N., \& Jatra, M. (2019). PENGARUH STORE ATMOSPHERE, DISPLAY PRODUCT, DAN PRICE DISCOUNT TERHADAP IMPULSE BUYING (Studi kasus pada Indomaret di kota Denpasar). E-Jurnal Ekonomi dan Bisnis Universitas Udayana 8.4(ISSN : 2337-3067), 369-394.

[2] Ghozali, I. (2013). Aplikasi Analisis Multivariate dengan Program IBM SPSS 21. Semarang: Badan Penerbit Universitas Diponegoro.

[3] Ghozali, I. (2014). Structural Equation Modeling, Metode Alternatif dengan Partial Least Square (PLS) (4 ed.). Semarang: Badan Penerbit Universitas Diponegoro.

[4] Laksana, M. F. (2019). Praktis Memahami Manajemen Pemasaran. Jawa Barat: Khalifah Mediatama.
Store Atmosphere and Impulse Buying

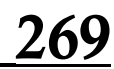


Store Atmosphere and Impulse Buying
[5] Keren, K. and Sulistiono, S., 2019. Pengaruh Motivasi, Budaya, dan Sikap Konsumen Terhadap Keputusan Pembelian Produk Indomie. Jurnal Ilmiah Manajemen Kesatuan, 7(3), pp.319-324.

[6] Maharani, P. D., \& Darma, G. S. (2018, September). Consumer Purchasing Behavior Analysis on Impulse Buying. Jurnal Manajemen dan Bisnis, Volume 15(No. 3). Dipetik Januari 2020, dari http://journal.undiknas.ac.id/index.php/magistermanajemen

[7] Mulyana, M., Mashadi, M. and Syahputri, A.W., 2020, May. Determinants of Millenial Consumer Purchasing Decisions in Bukalapak. In 2nd International Seminar on Business, Economics, Social Science and Technology (ISBEST 2019) (pp. 113-115). Atlantis Press.

[8] Mulyana, M., 2012. Consumer Behaviour: Sukses Dengan Memahami Konsumen.

[9] Muthiah, I., Parawansa, D. A., \& Munir, A. R. (2018, April). Pengaruh Visual Merchandising, Display Product, dan Store Atmosphere Terhadap Perilaku Impulse Buying (Studi Kasus: Konsumen Matahari Department Store Di Kota Makassar). Hasanuddin Journal of Applied Business and Entrepreneurship, Vol. 1(No. 2).

[10] Nurendah, Y., 2015. Strategy to Improvement Sustainability of Distinctively Local Snacks Based on Evaluation and Profile Mapping of SMEs Distinctively Local Snacks. International Journal on Advanced Science, Engineering and Information Technology, 5(5), pp.334-338.

[11] Pontoh, M. E., Moniharapon, S., \& Roring, F. (2017, Juni). PENGARUH DISPLAY PRODUK DAN STORE ATMOSPHERE TERHADAP IMPULSE BUYING PADA KONSUMEN MATAHARI DEPARTMENT STORE MEGA MALL MANADO, 5(2), 1823-1833.

[12] Pramiudi, U. and Setiawan, B., 2019. Penelusuran Persepsi Mahasiswa Atas Program Studi Akuntansi dan Minat Studi Lanjut. JAS-PT (Jurnal Analisis Sistem Pendidikan Tinggi Indonesia), 2(2), pp.103-113.

[13] Richard, M. (2019, Januari 07). 2019, Bisnis Ritel Modern Ditarget Tumbuh 10\%. (W. D. Herlinda, Editor) Dipetik Januari 22, 2020, dari Bisnis.com: https://www.google.com/amp/s/m.bisnis.com/amp/read/20190107/12/876089/ 2019-bisnis-ritel-modern-ditarget-tumbuh-10

[14] Setiawan, B., Afiff, A.Z. and Heruwasto, I., 2020. Integrating the Theory of Planned Behavior With Norm Activation in a Pro-Environmental Context. Social Marketing Quarterly, 26(3), pp.244-258.

[15] Sopiah, \& Sangadji, E. M. (2016). Salesmanship (Kepenjualan). Jakarta: PT Bumi Aksara.

[16] Sudaryana, B. (2017). Metode Penelitian. Yogyakarta: Deepublish.

[17] Sugiyono. (2014). METODE PENELITIAN MANAJEMEN. Bandung: Alfabeta.

[18] Sulistiono, S., Fadillah, A. and Putrie, D.E., 2020, May. Factors Affecting Bogor Botanical Garden Visitors' Intention Before and After the One Way System Application. In 2nd International Seminar on Business, Economics, Social Science and Technology (ISBEST 2019) (pp. 291-296). Atlantis Press.

[19] Sunawarman, A., Rohendi, A., \& Sofyan, I. (2018). Membangkit Spontanitas Belanja Pada Supermarket Melalui Promosi, Pramuniaga dan Atmosfer Toko. Jurnal Ecodemica, Vol. 2(No. 1).

[20] Top Brand Index Fase 2. (t.thn.). Dipetik Februari 11, 2020, dari TOP BRAND AWARD:

https://www.topbrand-award.com/top-brand-index/?tbi_find=Ramayana

[21] Utami, C. W. (2017). Manajemen Ritel. Jakarta: Salemba Empat

[22] Zuhdi, S., Rainanto, B.H. and Apriyani, D., 2020, May. Analysis of CoBranding Strategy to Improve Company's Competitive Power (Case Study on Walls Selection Oreo). In 2nd International Seminar on Business, Economics, Social Science and Technology (ISBEST 2019) (pp. 146-149). Atlantis Press. 